\title{
ASSORTMENT DOWNGRADE CORRECTION FOR CLEAR CUT OF Pinus taeda L. WITH USE OF TRANSITION MATRIX
}

\author{
Thiago Floriani Stepka1; Klerysson Júlio Farias² \\ ${ }^{1}$ Universidade do Estado de Santa Catariana, Centro de Ciências Agroveterinárias CAV/UDESC, Departamento de Engenharia Florestal, \\ Lages, Santa Catarina, Brasil. thiago.stepka@udesc.br \\ ${ }^{2}$ Universidade do Estado de Santa Catariana, Centro de Ciências Agroveterinárias CAV/UDESC, Curso de Engenharia Florestal, Lages, \\ Santa Catarina, Brasil. kjfarias.efl@gmail.com
}

Received for publication: 11/05/2020 - Accepted for publication: 17/04/2021

\begin{abstract}
Resumo
Correção do downgrade de sortimentos para corte raso de Pinus taeda L. com uso de matriz de transição. É importante que a quantificação do estoque de uma floresta seja determinada de maneira eficiente e precisa, de modo que seja desejável um maior detalhamento de informações para o conhecimento dos diferentes multiprodutos originados. No entanto, o emprego das funções de afilamento, método utilizado para a determinação dos sortimentos, não prevê o aparecimento de defeitos nos fustes que possam desqualificar as toras durante a colheita florestal. Este estudo teve como objetivo aplicar o método da matriz de transição, modelo tradicionalmente usado para prognosticar a estrutura diamétrica de florestas inequiâneas, para corrigir estimativas do sortimento realizadas por funções de afilamento, tais como falhas no processamento das árvores, que proporcionam uma desqualificação das toras nos valores de mercado. Adaptando-se o conceito da Cadeia de Markov, para a correção do downgrade de sortimentos pode-se obter a transição das classes de sortimento, dividindo-se o volume real obtido após a operação da máquina de colheita pelo volume estimado pela função de afilamento. Neste caso, aplicando-se esta alternativa para um cenário de corte raso de um plantio Pinus taeda de 16 anos, foi possível verificar a existência de mudanças, principalmente nas classes de sortimento com diâmetro da ponta fina de 24 e $18 \mathrm{~cm}$ e apresentando correção eficiente nas estimativas. Entretanto, ressalta-se que aferições realísticas da transição de sortimentos, mediante matrizes de probabilidade, devem ser construídas para cada plantio florestal ou talhão, viabilizando a correção das estimativas. Divergências entre máquinas processadoras ou qualificações de operadores florestais podem ser determinantes para a calibração do modelo. Palavras-chave: função de afilamento, processamento de toras, cadeia de Markov.
\end{abstract}

\begin{abstract}
It is very important that the quantification of a forest's stock is determined efficiently and accurately, in such a way that more detailed information is desirable for the knowledge of the different multiproducts originated. However, the use of taper functions, a precise adjustment method for determining the assortments, does not foresee the appearance of defects in the stem that could disqualify the logs during the forest harvest. This study aimed to use the transition matrix method, a model traditionally used for predict the diametric structure of uneven-aged forests, to correct assortment estimates made by tapering functions, such as failures in tree processing, that provide a disqualification of the logs in the market values. Adapting the concept of the Markov Chain, for the correction of the assortment downgrade, the transition of the assortment classes can be obtained by dividing the actual volume obtained after the operation of the harvesting machine by the volume estimated by the tapering function. In this case, applying this alternative to the clear cut of a 16-year-old Pinus taeda plantation, it was possible to verify the existence of changes, mainly in assortment classes with a thin end diameter of 24 and $18 \mathrm{~cm}$ and presenting efficient correction in the estimates. In order to make realistic corrections to the assortment transition, probability matrices must be built for each compartment or forest site to be estimated. Divergences between processing machines or forestry operator's qualifications can be decisive for the calibration of the model.

Keywords: taper function, log processing, Markov chain.
\end{abstract}

\section{INTRODUCTION}

Until the mid-1960s, lumber production in southern Brazil was solely linked to the use of the large native forest cover that existed in the region. Due to the intense exploitation without the application of any sustainable forest management technique, the forest cover of these areas has been converted into agricultural areas, pastures or forest plantations with exotic species mainly Pinus elliottii Engelm. and Pinus taeda L.

The forest-planting incentive policies adopted in the country in the 1960s (BRAZIL, 1966) boosted Brazilian silviculture, which currently corresponds to an area of 9 million hectares planted, of which $18 \%$ belong to the Pinus genus, which is widespread in more quantity in the southern region of the country. In this region, the forestry market is structured, with production divided between the cellulose, panels, sawn and biomass sector, moving a good part of the economy (IBÁ, 2020).

In view of the large number of products that can be obtained from the forest, it is of fundamental importance that the quantification of the stock is determined in an efficient and precise manner, in such a way that 
greater detail of information is desirable, since the forest owner should obtain the knowledge of the different multiproducts originated from the forest.

In this context, volumetric estimates made with the use of tapering functions, are indicated, mainly because they make estimates of the total volume of the tree and its multiproducts (Miguel et al. 2011; Figueiredo Filho et al. 2015; Kohler et al. 2013; Oliveira et al. 2020). However, it has been observed that the estimates made by these models, present certain inconsistencies with the values measured after the forest harvest (Serpe et al. 2018), and these errors are often considered not as a biased estimate of the models, but as defects in the logs or insipient quality of forest harvesting activities.

Studies like the one by Serpe et al. (2018), proposed the development of correction factors, called downgrade coefficients, whose purpose is to rectify the volume estimated by the tapering model from the verification of the volumes obtained after the forest harvest. However, the use of this coefficient is not sensitive to assess the transition that occurs between the different assortment classes as well as the indication of possible flaws in the process, such as the presence of tortuosities in the stem, damage to the bark in the logs or possible attacks of capuchin monkeys (Sapajus nigritus), factors that provide a disqualification of the logs in the market values.

There are mathematical models used mainly for the prognosis of the diametric structure of native forests, which evaluate the transition of trees over different classes of diameters in different monitoring periods. The transition matrices or Markov chain have been used mainly in studies of the dynamics of native forests (Austregésilo et al. 2004; Teresczcuch et al. 2007; Stepka et al. 2010; Reis et al. 2018). This model, represented by the matrix form, assumes that a tree in a diametric class has a probability of remaining in that class, moving to the next class, or dying (Stepka et al. 2010), requiring at least two monitoring of the forest for its construction. This original concept can be adapted to quantify changes in assortment estimates after processing the logs by the forestry machine.

This work used the transition matrix method to correct assortment estimates made by tapering functions. The hypothesis of this research is that the transition matrix model can be used as a strategy to observe the existence of changes between the assortment classes estimated by tapering models, with that observed after the forest harvest in shallow cut, identifying critical and possible points quality problems in forestry operations.

\section{MATERIALS AND METHODS}

\section{Study Area}

The database for processing and defining this methodology was collected in an area located in the municipality of Coronel Domingos Soares, state of Paraná, with a total of 11.4 hectares, planted with $P$. taeda at the age of 16 under spacing of $3 \mathrm{~m} \times 2 \mathrm{~m}$, without thinning.

\section{Data collection}

A forest inventory was carried out in the study area, through simple random sampling, where 12 circular units of $400 \mathrm{~m}^{2}$ of fixed area were installed, measuring 475 individuals, where it was possible to estimate the diametric distribution of the population (Figure 1).

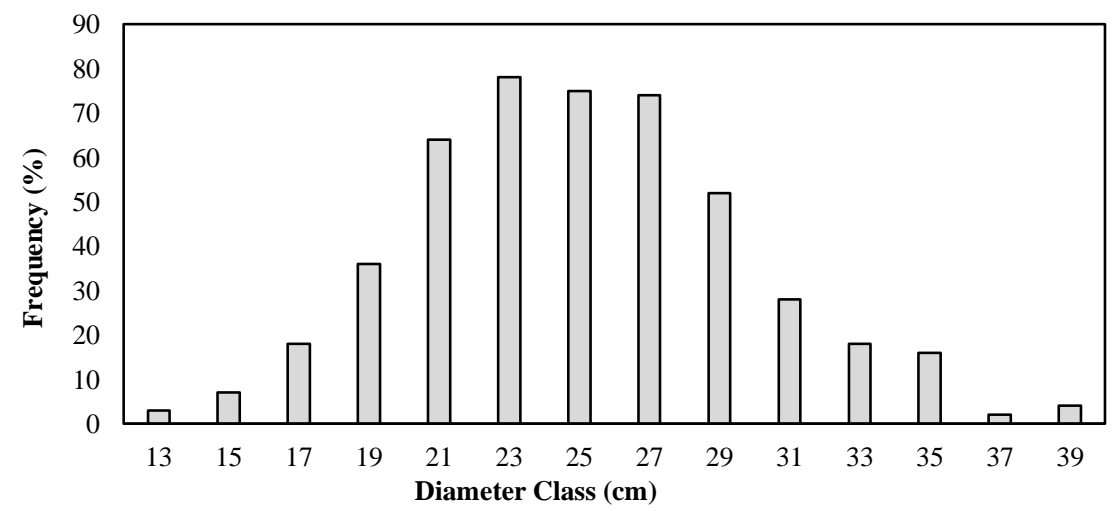

Figure 1. Diametric distribution of the inventoried population

Figura 1. Distribuição diamétrica da população inventariada

Comprising the entire diametric amplitude of the frequency histogram, 40 trees were selected. These were felled and delimbed with the aid of a Forest Harvester with a power of $104 \mathrm{~kW}(139 \mathrm{HP})$, operating weight of $22 \mathrm{t}$ (without head), reinforced track undercarriage, equipped with a head with an operating weight of $895 \mathrm{~kg}$ and maximum diameter cutting width of $570 \mathrm{~mm}$. Subsequently, cubing was performed using the modified 
Hohenadl method with sections at $0.5 \%, 1 \%, 5 \%, 10 \%, 15 \%, 20 \%, 25 \%, 30 \%, 40 \%, 50 \%, 60 \%, 70 \%, 80 \%, 90 \%$ and $95 \%$ of the total height.

Then, the trees were processed in logs, in the assortment dimensions used by the company that owns the area (Table 1), and the instant processing report issued by the software integrated with the machine's on-board computer was collected, aiming the analysis of the sensors calibration attached to the implement and the qualitative analysis of the operation.

Table 1. Assortments classes used in the company.

Tabela 1. Classes de sortimentos utilizados na empresa

\begin{tabular}{ccc}
\hline Class & dtl $(\mathbf{c m})$ & Length $(\mathbf{m})$ \\
\hline$S 1$ & 33 & 2.63 \\
$S 2$ & 24 & 2.54 \\
$S 3$ & 18 & 2.54 \\
$S 4$ & 13 & 2.54 \\
S5 & 8 & 2.45 \\
\hline
\end{tabular}

Where: $\mathrm{S} 1=\operatorname{logs}$ with a thin end diameter above $33 \mathrm{~cm}$ and a length of $2.63 \mathrm{~m} ; \mathrm{S} 2=\operatorname{logs}$ with a thin end diameter above $24 \mathrm{~cm}$ and a length of $2.54 \mathrm{~m} ; \mathrm{S} 3=\operatorname{logs}$ with a thin end diameter above $18 \mathrm{~cm}$ and a length of $2.54 \mathrm{~m} ; \mathrm{S} 4=\operatorname{logs}$ with a thin end diameter above $13 \mathrm{~cm}$ and a length of $2.54 \mathrm{~m} ; \mathrm{S} 5=\operatorname{logs}$ with a thin end diameter equal to or greater than $8 \mathrm{~cm}$ and a length of $2.45 \mathrm{~m}$; dtl = diameter obtained at the thin end of the $\log (\mathrm{cm})$.

After processing the 40 trees and stacking the logs, according to the different assortment classes, the diameters (thick tip and thin tip) and the length of the logs were measured. Subsequently, cubing was performed by the Smalian method and validation of the estimates of the software coupled to the Harvester.

The cubing data (Hohenadl and Smalian) were tabulated in electronic spreadsheets and the adjustment of two models (Table 2) of taper functions (from the cubes by Hohenadl) was carried out, in order to make assortment estimates.

Table 2. Taper models used to express the steam profile and to estimate the forest assortments.

Tabela 2. Modelos de afilamento utilizados para expressar perfil do tronco das árvores e estimar o sortimento da floresta

\begin{tabular}{ccc}
\hline Model & Author & Mathematical formulation \\
\hline 1 & Kozak et al. (1969) & $y^{2}=\beta_{0}+\beta_{1} x+\beta_{2} x^{2}$ \\
2 & Schöepfer (1966) & $y=\beta_{0}+\beta_{1} x+\beta_{2} x^{2}+\beta_{3} x^{3}+\beta_{4} x^{4}+\beta_{5} x^{5}$
\end{tabular}

Where: $\mathrm{y}=\frac{d i}{d} ; \mathrm{x}=\overline{\frac{h i}{h}} ; \mathrm{di}=$ stem diameter at $h_{i}$ height $(\mathrm{cm}) ; \mathrm{d}=\operatorname{diameter}$ at breast height $(\mathrm{cm}) ;$ hi $=$ stem height at a given section $(\mathrm{m}) ; \mathrm{h}=$ total height $(\mathrm{m})$;

Through the best adjusted tapering model, selected through adjustment statistics (higher adjusted $\mathrm{R}^{2}$, lower Syx \% and homogeneous dispersion of residues), assortments were estimated and the results obtained in the equation were compared with those obtained after processing the logs with the Harvester. The volumetric estimates were obtained from the integral of the best selected tapering function.

\section{Correction of the assortment estimate with a transfer matrix}

Estimates of the assortments of the trees, by adjusting mathematical equations, do not predict the fact that they present tortuosity or other defects such as bifurcations, pest attacks, etc., although classification codes of the shafts can be elaborated and could be used in the reduction of commercial volumes. However, it requires a different approach for processing in each quality code, which can be difficult to implement in some situations.

According to Serpe et al. (2018) the downgrade of an assortment is defined as the lowering, reclassification or migration of a log with a larger diameter to the assortment class of logs with smaller diameter, reducing its economic potential. According to these authors, the downgrade of assortments may also be the result of mechanical factors in forest harvesting, due to the breaking of the stem or imprecision of the processing heads that can generate errors in the diameter and length of the logs.

The downgrade coefficients for assortment are calculated by dividing the actual volume processed in the field by assortment and the estimated volume by assortment, according to the expression:

$$
d c a=\frac{v c}{v e}(1)
$$


Where: $\mathrm{dca}=$ downgrade coefficient for assortment; $\mathrm{vc}=$ volume obtained from assortment class after log processing (field); ve = volume estimated from assortment class (estimated by taper function).

To obtain the volume correction, using the downgrade coefficient, the following expression is used:

$$
v c=v e . d c a
$$

However, when working with different assortment classifications, it is necessary to know the downgrade coefficient for the different classes evaluated or, within the assortment class estimated by the tapering functions, to identify and quantify the main losses due to defects in the logs or inaccuracies in the mechanical processes of forest harvesting.

Such a procedure can be identified with an adaptation of the transition matrix. The mathematical model, traditionally used to predict the diametric structure of unequal forests, has as a characteristic, according to Azevedo et al. (1995), that the probability of tree transition for each measurement interval is obtained by dividing the number of trees that died, changed classes or remained in the same class by the number of trees in that class at the beginning of the growth period. Thus, adapting the concept for correcting the assortment downgrade, it is possible to obtain the transition of the assortment classes, dividing the actual volume obtained, after the operation of the harvesting machine, by the volume estimated by the tapering function. Therefore, the matrix model can be represented as follows:

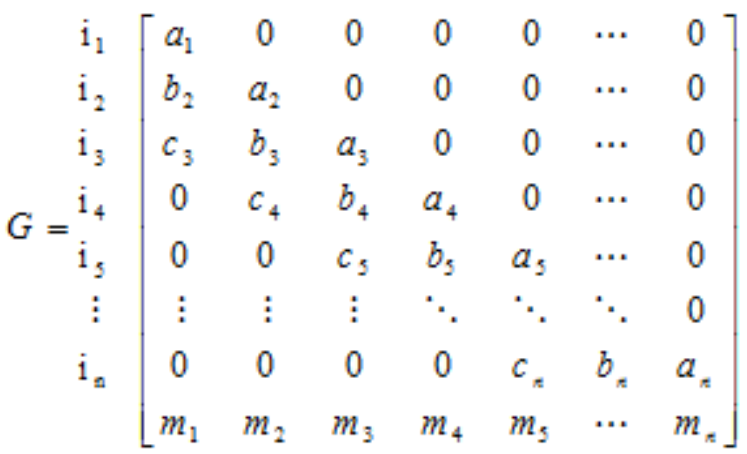

Where: $\mathrm{G}=$ transition probability matrix; in = "i"-assortment class; ai, bi, ci = the probabilities of the volume estimated by the tapering model for an assortment class to remain in the same class during the processing of logs in the field (ai), change to the subsequent assortment class (bi), or change to two subsequent assortment classes (ci); mi = Probability of volumes estimated by the tapering model that were disqualified due to some defect in the stem or by pest attacks.

Also, in matrix G, transitions may occur to the right of the main diagonal, which in these cases would correspond to a change of classes for larger assortments.

In cases where factors disqualify the assortment classes, such as pest attack or defects in the stem, the "mi" probability can occupy more than one line in the probability matrix $(\mathrm{G})$, incorporating each defect class to a new line. These defect classes are not used in matrix multiplication, their values are considered only in the total probability.

Thus, the corrected estimate of the assortments obtained from the taper function is the result of multiplying the transition probability matrix by the estimated volume for each assortment class, as follows:

$$
\mathrm{Y}_{\Delta}=\mathrm{G} \cdot \mathrm{Y}_{i}
$$

Where: $\mathrm{Y} \Delta=$ corrected volume of the assortment classes; $\mathrm{G}=$ probability of transition by assortment class; $\mathrm{Y} i=$ volume of each assortment class estimated by the taper function.

The matrix form of expression 3 is:

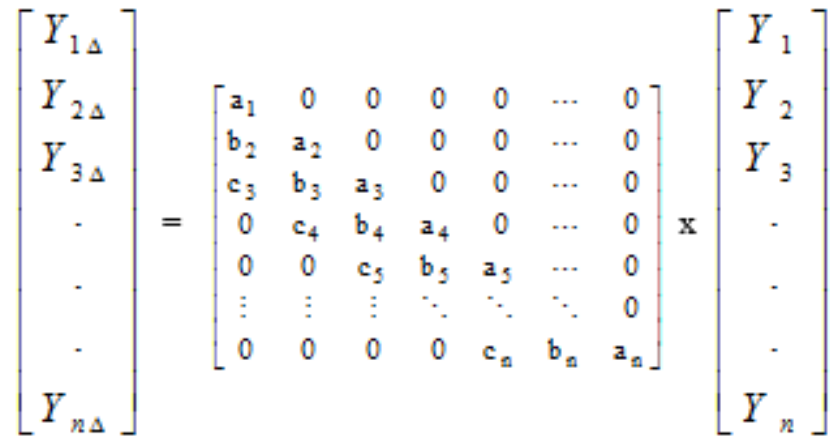


To obtain the necessary subsidies to build the probability matrix, it was used the data from the cubes of the log stacks from each of the 40 felled trees, where, for each tree, can be calculated the volume of each assortment class after processing in logs by the Smalian method.

Also, for each tree, the volume of each of the assortment classes was estimated, being possible to compute in a spreadsheet, the total volume estimated for each assortment and that obtained in the field after processing.

To ascertain the efficiency of the measurements, it was verified the percentage variation occurred between the volumes estimated by the equations, those obtained after processing the logs and the obtained on the on-board computer of the forest harvesting machine, as follows:

$$
\begin{aligned}
& \Delta v_{1}=\frac{(v e-v c)}{v e} .100(4) \\
& \Delta v_{2}=\frac{(v e-v h)}{v e} .100(5)
\end{aligned}
$$

Where: $\Delta v 1=$ Difference in percentage of the volume $\left(\mathrm{m}^{3}\right)$ estimated by the tapering function and the volume $\left(\mathrm{m}^{3}\right)$ obtained after processing; $\Delta \mathrm{v} 2=$ Difference in percentage of the volume $\left(\mathrm{m}^{3}\right)$ estimated by the tapering function and the volume $\left(\mathrm{m}^{3}\right)$ obtained in the Harvster's on-board computer; vc = volume $\left(\mathrm{m}^{3}\right)$ obtained by assortment class after processing the $\operatorname{logs}$ (field); ve $=$ volume $\left(\mathrm{m}^{3}\right)$ estimated by assortment class (estimated by the taper function); $\mathrm{vh}=$ volume $\left(\mathrm{m}^{3}\right)$ obtained from the Harvester's on-board computer.

Interpreting the results, if $\Delta v_{n}$ presents positive values, it is indicated that there is overestimation of the volumes due to the tapering function, otherwise underestimation occur.

In the expectation of evaluating the reliability of the volumes estimated from the equation, after correction with the multiplication of the probability matrix, the eec (equation error coefficient ) was calculated, as follows:

$$
\text { eec }=\frac{v c \%}{v e c \%}
$$

Where: eec $=$ equation error coefficient; $\mathrm{vc} \%=$ percentage of the volume obtained from assortment class after processing the logs (field); vec\% = percentage of the volume estimated and corrected by the taper function and transition matrix.

The eec calculation informs the percentage of assertiveness of the presented methodology, that is, the closer to 1 the result, the more accurate is the estimate.

In addition, a comparison was made between the volume obtained after processing the logs, with the estimated volume and with the volume corrected by the transition matrix, using the Kolmogorov-Smirnov (K-S) test at $99 \%$ probability. The test is focused on the biggest difference between two distributions. The formula for measuring possible discrepancies between observed and estimated proportions is described below.

$$
D=>V c-V e(7)
$$

Where: $\mathrm{Vc}=$ Accumulated volume obtained after processing the logs (field) for each class of assortment; Ve = Estimated or estimated and corrected accumulated volume for each assortment class; D = Point of greatest divergence from K-S;

The significance of the test completion is given by the following equation:

$$
\text { Dcalc }=D / V(8)
$$

Where: $\mathrm{D}=$ Value of greatest divergence between the compared volumes; $\mathrm{V}=$ volume total obtained in the field after processing the logs.

- $\quad$ If Dcalc is $\geq \mathrm{Dn}$ : Ho is rejected (volumes in the assortment classes are statically different).

- If Dcalc is <Dn: Ho is accepted (volumes in the assortment classes are statically equal).

The Dn value is tabulated at the $\alpha$ level of probability obtained for the total volume after processing the logs. The lowest Dcalc value, between the different comparisons, indicates the most efficient alternative.

\section{RESULTS}

The trees cubed by the Hohenadl method showed an average of $25.1 \mathrm{~cm}$ dap, $21.1 \mathrm{~m}$ in height, 0.5112 $\mathrm{m}^{3}$ in volume and an average artificial form factor of 0.48 
The adjustments of the two tapering models show coefficients and statistics shown in Table 3. Notably, the adjusted determination coefficient and standard error in percentage were recalculated for the variable di $(\mathrm{cm})$.

Table 3. Coefficients and statistics of taper equations.

Tabela 3. Coeficientes e estatísticas dos modelos de afilamento testados.

\begin{tabular}{|c|c|c|c|c|c|c|c|c|}
\hline Model & $\boldsymbol{\beta}_{0}$ & $\beta_{1}$ & $\boldsymbol{\beta}_{2}$ & $\beta_{3}$ & $\boldsymbol{\beta}_{4}$ & $\beta_{5}$ & $\mathbf{R}^{2}$ Adjusted & $\mathrm{S}_{\mathrm{yx}}(\%)$ \\
\hline 1 & 1.4837 & -1.5465 & 0.0654 & - & - & - & 0.9692 & 8.71 \\
\hline 2 & 1.1971 & -3.4264 & 14.3655 & -31.7613 & 31.1112 & -11.4972 & 0.9788 & 7.23 \\
\hline
\end{tabular}

Where: $\beta_{\mathrm{n}}=$ Model coefficient; $\mathrm{R}^{2}$ Adjusted = Coefficient of determination adjusted; $\mathrm{S}_{\mathrm{yx}}(\%)=$ Standard error of percentage estimate

The taper models showed an adjusted $\mathrm{R}^{2}$ greater than $95 \%$, with a standard error of the maximum estimate of $8.71 \%$. Considering the adjustment statistics, it was found that the Schöepfer model (1966) showed better results, which was chosen to represent the profile of the trees evaluated and to estimate the assortment of logs.

\section{Assortment prediction and analysis of log loss and class changes}

The results of the assortment estimates of the 40 trees by the tapering model, the cubing in the log yard calculated by the Smalian method after processing and the data from the Harvester report are shown in Table 4.

Table 4. Volumes comparison obtained by taper function, Harvester report and by the Smalian cubing method of trees in the field.

Table 4. Volumes comparison obtained by the tapering function, the Harvester report and the Smalian cubing method of trees in the field.

\begin{tabular}{ccccccc}
\hline Description & S1 & S2 & S3 & S4 & S5 & Total \\
\hline vc $\left(\mathrm{m}^{3}\right)$ & 0.5599 & 5.6084 & 7.4876 & 3.8099 & 1.4832 & 18.9490 \\
ve $\left(\mathrm{m}^{3}\right)$ & 0.5904 & 6.9034 & 7.2896 & 4.1172 & 1.8043 & 20.7048 \\
vh $\left(\mathrm{m}^{3}\right)$ & 0.5414 & 6.1055 & 7.9875 & 3.9972 & 0.9191 & 19.5507 \\
$\Delta \mathrm{v} 1$ & $5.2 \%$ & $18.8 \%$ & $-2.7 \%$ & $7.5 \%$ & $17.8 \%$ & $8.5 \%$ \\
$\Delta \mathrm{v} 2$ & $8.3 \%$ & $11.6 \%$ & $-9.6 \%$ & $2.9 \%$ & $49.1 \%$ & $5.6 \%$ \\
\hline
\end{tabular}

Where: $v c=$ volume obtained in the field by the Smalian method after Harvester processing; ve = volume estimated by the taper function; vh $=$ volume obtained from the Harvester's on-board computer; $\Delta \mathrm{v} 1=$ Difference in percentage of the volume estimated by the volume obtained after processing. $\Delta \mathrm{v} 2=$ Difference in percentage of the volume estimated by the volume obtained on the Harvster's on-board computer; $\mathrm{S} 1=$ Logs with thin end diameter above $33 \mathrm{~cm}$ and a length of $2.63 \mathrm{~m}$; S2 = Logs with a thin end diameter above $24 \mathrm{~cm}$ and a length of $2.54 \mathrm{~m}$; S3 $=$ Logs with a thin end diameter above $18 \mathrm{~cm}$ and a length of $2.54 \mathrm{~m} ; \mathrm{S} 4=\mathrm{Logs}$ with thin end diameter above $13 \mathrm{~cm}$ and a length of $2.54 \mathrm{~m}$; $\mathrm{S} 5=\log$ s with a thin end diameter $\geq 8 \mathrm{~cm}$ and a length of $2.45 \mathrm{~m}$.

In addition to the volumes shown in Table 4, another influential factor in this result is the attack of the capuchin monkey ( $S$. nigritus), observed after the felling and processing of the trees, such values represent a total loss of $0.8675 \mathrm{~m}^{3}$, that is, $4,2 \%$ of the total volume. Also noteworthy is the volume that is lost due to breaks $\left(0.2009 \mathrm{~m}^{3}\right.$ or $1 \%$ of the total), which occur at the time of the felling because Harvester cannot mitigate their fall.

By comparing the information of the volumes estimated by the taper function with the cubing in the log yard after processing, the probability matrix can be constructed, Table 5.

Table 5. Probability matrix of transition assortments

Tabela 4. Matriz de probabilidade de transição dos sortimentos.

\begin{tabular}{cccccc}
\hline \multirow{5}{*}{ vc } & \multicolumn{5}{c}{ ve } \\
\cline { 2 - 6 } & $\boldsymbol{S 1}$ & $\boldsymbol{S 2}$ & $\boldsymbol{S 3}$ & $\boldsymbol{S 4}$ & $\boldsymbol{S 5}$ \\
\hline $\boldsymbol{S 1}$ & $1.000^{*}$ & 0.000 & 0.000 & 0.000 & 0.000 \\
$\boldsymbol{S 2}$ & $0.000^{* *}$ & $0.768^{*}$ & $0.016^{\mathrm{up}}$ & 0.000 & 0.000 \\
$\mathbf{S 3}$ & 0.000 & $0.232^{*}$ & $0.877^{*}$ & $0.048^{\text {up }}$ & 0.000 \\
$\mathbf{S 4}$ & 0.000 & 0.000 & $0.071^{* *}$ & $0.768^{*}$ & $0.095^{\text {up }}$ \\
$\mathbf{S 5}$ & 0,000 & 0.000 & 0.000 & $0.113^{* *}$ & $0.641^{*}$ \\
$\mathbf{M p}$ & 0.000 & 0.000 & 0.036 & 0.071 & 0.153 \\
$\boldsymbol{B k}$ & 0.000 & 0.000 & 0.000 & 0.000 & 0.111
\end{tabular}

Where: $v c=$ volume obtained in the field by the Smalian method after Harvester processing; ve = volume estimated by the taper function; 1 $=$ Logs with a thin end diameter above $33 \mathrm{~cm}$ and a length of $2.63 \mathrm{~m}$; S2 $=$ Logs with a thin end diameter above $24 \mathrm{~cm}$ and a length of $2.54 \mathrm{~m}$; 
$\mathrm{S} 3=\mathrm{Logs}$ with a thin end diameter above $18 \mathrm{~cm}$ and a length of $2.54 \mathrm{~m} ; \mathrm{S} 4=\mathrm{Logs}$ with a thin end diameter above $13 \mathrm{~cm}$ and a length of 2.54 $\mathrm{m} ; \mathrm{S} 5=\operatorname{logs}$ with a thin end diameter equal to or greater than $8 \mathrm{~cm}$ and a length of $2.45 \mathrm{~m} ; \mathrm{Mp}=$ attacked by a capuchin monkey; Bk = broken during processing; * probability/percentage of volumes that were estimated for a given assortment class and that remained in the same class after processing; $* *$ probability / percentage of volumes that were estimated for one assortment class, but migrated to the next class; up $=$ probability / percentage of volumes that were estimated for an assortment class, but migrated to the upper class (upgrade).

It was possible to calculate the percentage of volumes that changed assortment classes and, by multiplying the probability matrix by the volumes estimated by the taper function, the corrected volumes were obtained. Table 6 shows the values of the volumes estimated by the tapering function, obtained in the field after processing the machine and corrected after multiplication by the probability matrix. The percentages of volume in each assortment class and the error coefficient of the equation are also shown.

Only the use of this matrix would be an adequate method for correcting the assortments, however, the error present in the inventory or even in the equation must be considered. Thus, an equation error coefficient (eec) was determined, which is also available in Table 6.

Table 6 - Corrected estimate after multiplication by the assortment transition matrix.

Tabela 5 - Estimativa corrigida após a multiplicação pela matriz de transição dos sortimentos.

\begin{tabular}{cccccccc}
\hline Assortment & $\mathbf{v c}\left(\mathbf{m}^{\mathbf{3}}\right)$ & ve $\left(\mathbf{m}^{\mathbf{3}}\right)$ & vec $\left(\mathbf{m}^{3}\right)$ & vc \% & ve \% & vec \% & eec \\
\hline S1 & 0.5599 & 0.5904 & 0.5904 & $3.0 \%$ & $2.9 \%$ & $3.0 \%$ & 0.98 \\
S2 & 5.6084 & 6.9034 & 5.7887 & $29.6 \%$ & $33.3 \%$ & $29.5 \%$ & 1.00 \\
S3 & 7.4876 & 7.2896 & 7.7197 & $39.5 \%$ & $35.2 \%$ & $39.3 \%$ & 1.01 \\
S4 & 3.8099 & 4.1172 & 3.9156 & $20.1 \%$ & $19.9 \%$ & $19.9 \%$ & 1,01 \\
S5 & 1.4832 & 1.8043 & 1.6220 & $7.8 \%$ & $8.7 \%$ & $8.3 \%$ & 0.95 \\
\hline
\end{tabular}

$\begin{array}{lllllll}\text { Total Geral } & 18.9490 & 20.7048 & 19.6365 & 100 \% & 100 \% & 100 \%\end{array}$

Where: $\mathrm{vc}=$ volume obtained in the field by the Smalian method after Harvester processing; ve = volume estimated by the taper function; vc $=$ volume corrected after multiplication by the probability matrix; vec $=$ corrected estimate; eec $=$ equation error coefficient

It was observed that the estimate remained close to the value obtained in the field, mainly from S1 to S4. The smallest assortment, S5, was the one with the lowest coefficient, indicating that $95 \%$ of the corrected estimate is appropriate, and the remaining 5\% may indicate the error present in the taper function equation, or the breaks and losses due to the attack of capuchin monkeys. The Kolmogorov-Smirnov test presented a Dcalc of 0.09266, for the comparison between "vc" and "ve" and a Dcalc of 0.03627 in the comparison between "vc" and "vec." The Dn value was 0.3744 , that is, with the test result it can be concluded that in both comparisons there was equality between the estimates and value processed in the field. However, the Dcalc value of the comparison between "vc" and "vec" was lower, which characterizes the greater precision of "vec" compared to "ve."

Figure 2 shows the volume distribution, where it is possible to see the discrepancy in the volume estimate by the taper function, mainly in class $\mathrm{S} 2$, and its correction after multiplication by the probability matrix.

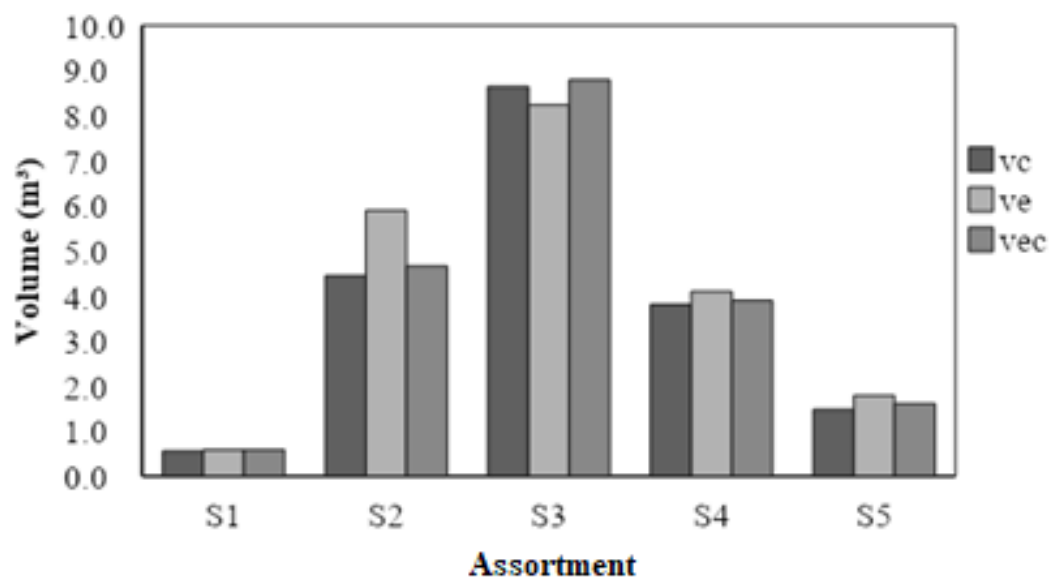

Where: $v c=$ volume obtained in the field by the Smalian method after Harvester processing; ve = volume estimated from taper function; vc $=$ corrected volume after multiplication by the probability matrix; vec = corrected estimate

Figure 2. Assortment distribution estimated by the taper function, obtained in the field after processing and in the corrected estimate.

Figura 2. Distribuição dos sortimentos estimado pela função de afilamento, obtido a campo após o processamento e na estimativa corrigida. 


\section{DISCUSSION}

The information generated by the assortment estimate does not always present values consistent with those obtained after processing the logs. Serpe et al. (2018), Campos; Tavares (2010) among other authors have verified these characteristics in their work. Estimates, on many occasions, can be inconsistent because problems are related to forest harvesting, such as declivity (Fielder et al. 2013), which can cause problems at the height of the tree stump and, consequently, interfere in the heights of tracing of the logs, generating losses in the quality of the assortment.

Other inconsistencies can happen according to the equipment or harvesting system used, mechanized or semi-mechanized. In poorly mechanized operations, the problems can be related to cracks and defects at the base of the first log, where training of operators can provide improvements in the forest-cutting process (Pereira et al. 2012). They can also be caused by biological problems of plants such as bifurcations and tortuosity (Serpe et al., 2018), which in some situations make the commercial use of logs unfeasible.

Inconsistencies between the estimates and reports generated by the processor software are considerable. Table 4 shows the volume values by assortment class estimated from taper models, observed in the field after processing the logs and obtained in the Harvester software. When evaluating the total results, there is less variation between the volume estimated from taper function and obtained by the Harvester $(5.6 \%)$, while the variation between the volume estimated from taper function and the processed was $8,5 \%$. However, the highest proportion of error evaluated was found in class S5, that is, $17.8 \%$ and $49.1 \%$, respectively for comparisons of the volume estimated from the function with that processed and with that obtained from the Harvester software. Here, the sensors in the head were not accurate to compute the diameters of the logs in these assortment classes, due to the small dimensions they presented.

Many of these discrepancies in the estimates can be seen in the transition probability matrix of the assortment volumes, where, for example, $76.8 \%$ of the estimated volumes for the S2 class remain the same after processing and, $23.2 \%$ migrated to the class S3 (less qualified), such circumstances can be attributed to several factors that have already been presented. It is noteworthy, with greater visibility the losses caused by breaks and by capuchin monkey attacks, where of the estimated volume for class S5, for example, there was a percentage of losses of $11.1 \%$ and $15.3 \%$, respectively.

Breaks are caused mainly in the thinnest logs (S4 and S5), which are found at the top of the trees and suffer the greatest impact during the felling. Damage by capuchin monkeys, on the other hand, have a greater proportion in the S5 (15.3\%) assortment logs, followed by S4 (7.1\%) and S3 (3.6\%), that is, the greater the height of the tree that the log is located, the greater the probability of attack by the capuchin monkey. Liebsch et al. (2013) reported that the damage caused by the attack of this animal is more evident in the upper third of the trees, and that $23 \%$ of the damage would be below $7 \mathrm{~m}$ for younger trees. Despite providing considerable drops in the quality of the wood, and mainly to the physiology of the plant due to girdling (Liebsch et al., 2013), the losses caused by the capuchin monkey in terms of log quality are less impactful because it focuses on the less qualified logs, but they can cause the death of the trees in many cases. Such breaks and defects are one of the main reasons for the divergences that occurred in these classes in the comparisons between the estimated and processed volumes.

In some situations, the volumes of the assortment classes S5 were upgraded to S4 (9.5\%), S4 to S3 (4.8\%) and S3 to S2 (1.6\%), not attributing to a factor characteristic for this change that are not the same caused by the disqualification. Works such as those by Oliveira et al. (2020) generated scenarios of volumetric and economic gain from changes in the height of the tree stumps, or even in few changes in the length of the logs. Such changes may be caused unintentionally by the forest machine operator and may cause the transition (upgrade or downgrade) of assortments in some cases.

After multiplying the estimated volume via the taper function by the probability matrix, there was a considerable improvement in the assortment class estimates (Figure 2). It is noticed that the tendency of overestimation in class S2 and underestimation in class S3, was corrected after multiplication by the probability matrix. Table 6 shows that after correcting the estimated volume (vec), the total volume of the 40 trees used in this study $\left(19.6365 \mathrm{~m}^{3}\right)$, was closer to the volumes calculated in the field after processing $\left(18.9490 \mathrm{~m}^{3}\right)$. Comparing the 5 assortment classes, based on the equation error coefficient (eec), it was found that the first 4 (most valuable) classes obtained a maximum error (underestimation) of 2\%; while the last class (less qualified) obtained a maximum error of 5\%, being, therefore, promising improvements for correcting the estimates. Even though there is equality, by the K-S test, in the estimated volumes (without the correction) with the volumes obtained after the processing of the logs, there is greater precision in the estimated and corrected volumes (vec).

In addition to the biometric impacts in the assortment prediction, these uncorrected estimates can provide considerable economic losses (Serpe et al., 2018), since they can estimate non-existent gross revenues in better qualified classes, as happened, for example, in approximately $23.2 \%$ of the volume that had been estimated for class $\mathrm{S} 2$, which actually belonged to class $\mathrm{S} 3$. 


\section{CONCLUSIONS}

The results obtained in this study demonstrate that:

- The application of the transition matrix was efficient to correct the assortments estimate, mainly of the intermediate classes of the assortments.

- It was possible to identify the transition of assortments that occurred from the estimated volume to the volumes processed in the field.

- The assortment classes most attacked by pests, breaks or defects in the trunk were identified.

- There was a downgrade in assortment classes, but also an upgrade in some others, possibly due to operational failures of forest harvesting machines.

- The methodology proved to be efficient and sensitive for detecting flaws in the quality process of forestry operations.

- To make realistic corrections to the assortment transition, probability matrices must be constructed for each compartment, or forest site that is wished to assess the estimates.

- Divergences between processing machines or qualifications of forestry operators can be decisive for the calibration of the model.

\section{REFERENCES}

AUSTREGÉSILO, S. L.; FERREIRA, R. L. C.; SILVA, J. A. A.; SOUZA, A. L.; MEUNIER, I. M. J.; SANTOS, E. S. Comparação de métodos de prognose da estrutura diamétrica de uma floresta estacional semidecidual secundaria. Revista Árvore, Viçosa, MG, v.28, n.2, p.227-232, 2004.

AZEVEDO, C. P.; SOUZA, A. L.; JESUS, R. M. Um modelo de matriz de transição para prognose do crescimento de um povoamento natural remanescente não manejado de mata atlântica. Revista Árvore, Viçosa, MG, v.19, n.2 p.187-199, 1995.

BRASIL, Lei $\mathrm{n}^{\circ}$ 5.106, de 2 de setembro de 1966. Dispõe sobre os incentivos fiscais concedidos a empreendimentos florestais. Diário Oficial União, Brasília, DF, 5 set. 1966.

CAMPOS, C.; TAVARES, M. Influência do comprimento e origem do toro na optimização do aproveitamento e do valor de rolos de pinho bravo. Silva Lusitana, Lisboa, v.18, n.1, p.123-132, 2010.

INDÚSTRIA BRASILEIRA DE ÁRVORES. Relatório IBA 2020. Disponível em: < https://iba.org/datafiles/publicacoes/relatorios/relatorio-iba-2020.pdf.> Acessado em: 19 de abril 2021.

FIEDLER, N. C.; CARMO, F. C. de A.; SÃO TEAGO, G. B.; CAMPOS, A. A. de; SILVA, E. N. da. Análise da qualidade da colheita florestal de eucalipto em diferentes declividades. Revista Científica Eletrônica de Engenharia Florestal, Garça, v. 22, n. 1, 2013.

FIGUEIREDO FILHO, A.; RETSLAFF, F.A.S.; KOHLER, S.V.; BECKER, M.; BRANDES, D. Efeito da idade no afilamento e sortimento em povoamentos de Araucaria angustifolia. Revista Floresta e Ambiente, Seropédica, RJ, v. 22, p. 50-59, 2015.

KOHLER, S.V.; KOEHLER, H.S.; FIGUEIREDO FILHO, A. Modelos de afilamento para Pinus taeda por classes de idade. Revista Floresta e Ambiente, Seropédica, RJ, p. 470-479, 2013.

KOZAK, A.; MUNRO, D. D.; SMITH, J. H. G. Taper functions and their application in Forest inventory. Forestry Chronicle, Quebec, v. 45, n. 4, p. 278-283, 1969.

LIEBSCH, D.; MIKICH, S. B; OLIVEIRA, E. B.; MOREIRA, J. M. M. A. P. Descascamento de Pinus taeda por macacos-prego (Sapajus nigritus): tipos e intensidades de danos e seus impactos sobre o crescimento das árvores. Scientia Forestalis, Piracicaba, SP, v. 43, n. 105, p. 37-49, 2015.

MIGUEL, E.P.; MACHADO, S. do A.; FIGUEIREDO FILHO, A.; ARCE, J.E.; Modelos polinomiais para representar o perfil e o volume do fuste de Eucalyptus urophylla na região norte do Estado de Goiás. Revista Floresta, Curitiba, PR, v. 41, n. 2, p. 355-368, 2011.

OLIVEIRA, G. S.; SOARES, P. R. C.; SAMPIETRO, J. A.; da SILVA, M. T. S.; NICOLETTI, M. F.; da SILVA, J. P. Evaluation of assortments considering different stump and pre-bucking disc heights in mechanized harvesting operations of a Pinus taeda L. forest. Revista Floresta, Curitiba, PR, v. 50, n. 1, p. 1133 - 1142, 2020. 
PEREIRA, D. P.; FIEDLER, N. C.; GUIMARÃES, P. P.; MÔRA, R.; BOLZAN, H. M. R.; PLASTER, O. B.; Avaliação da qualidade do corte florestal com motosserra. Revista Cerne, Lavras, MG, v. 18, n. 2, p. 197-203, abr./jun. 2012.

REIS, L. P.; TORRES, C. M. M. E.; SOUZA, A. L. FREITAS, L. J. M.; REIS, P. C. M. R.; SILVA, L. F.; LEITE, R. V. Prognose da distribuição diamétrica por matriz de transição em floresta após colheita no leste da Amazônia. Ciência Florestal, Santa Maria, RS, v. 28, n. 2, p. 715-724, 2018.

SCHÖEPFER, W. Automatisierung des Massem, Sorten und Wertberechnung stenender Waldbestande Schriftenreihe Bad. [S.I]: Wurtt-Forstl. 1966.

SERPE, E. L.; FIGUEIREDO FILHO, A.; ARCE, J. E. Coeficientes downgrade para sortimentos de toras de Pinus. BIOFIX Scientific Journal, Curitiba, PR, v. 3 n. 1 p. 116-121, 2018.

STEPKA, T. F.; DIAS, A. N.; FIGUEIREDO FILHO, A.; MACHADO, S. A.; SAWCZUK, A. R. Prognose da estrutura diamétrica de uma Floresta Ombrófila Mista com os métodos razão de movimentos e matriz de transição. Pesquisa Florestal Brasileira, Colombo, PR, v. 30, n. 64, p. 327-335, 2010

TERESCZCUCH, S. M..; MAC DONAGH, P. M..; OlIVEIRA, A. J.; RIVERO, L. E., BULFE, N. M. L. Predicción de la estructura diamétrica de especies comerciales de un bosque subtropical por medio de matrices de transición. Revista Floresta, Curitiba, PR, v.37. n.1.p 71-82, 2007. 